\title{
CYTOTOXICITY OF WATER EXTRACTS FROM LEAVES AND BRANCHES OF PHILADELPHUS CORONARIUS L.
}

\author{
Vojtech Valko, Maria Fickova ${ }^{\mathrm{b}}$, Eliska Pravdova ${ }^{\mathrm{b}}$, Milan Nagy ${ }^{\mathrm{a}}$, \\ Daniel Grancai ${ }^{a}$, Szilvia Czigle ${ }^{a}$
}

\author{
a Department of Pharmacognosy and Botany, Faculty of Pharmacy, Comenius University, Odbojárov 10, 83232 Bratislava, \\ Slovak Republic,e-mail:valko@fpharm.uniba.sk \\ ${ }^{b}$ Institute of Experimental Endocrinology SAS, Vlárska 3, 83306 Bratislava
}

Received: March 17, 2006; Accepted (with revisions): June 7, 2006

Keywords: Philadelphus coronarius L./Plant water extracts/A431 cells/MCF-7 cells/MTT cytotoxicity

Philadelphus coronarius L. is big, leggy and deciduous old-fashioned shrub known for its fragrant white flowers in the late spring. Some members of genus Philadelphus L. are known for their antibacterial, antiradical and immunomodulatory effects. Therefore, these herbs represent prospective sources for the isolation of active substances with desired effects.

We have investigated the cytotoxicity effects of water extracts from leaves and branches of Philadelphus coronarius L. (Hydrangeaceae). A431 cells (human skin carcinoma cell line) and the human breast adenocarcinoma cell line (MCF-7) were treated with various doses of individual extracts (0,1-100 $\mu \mathrm{g}$ dry matter/ml) for $24 \mathrm{~h}$ and $72 \mathrm{~h}$. The highest toxic effects of both plant parts extracts were observed on MCF-7 cells regardless the time of treatment. Cells A431 were less sensitive to toxic effects of leaves and branches extracts but the time dependence was present with the tendency of increased toxicity after chronic treatment. There were no differences in the extent of toxic effects between branches and leaves extracts. The results obtained so far will provide the basis for the future studies with isolated active substances from these extracts.

\section{INTRODUCTION}

The use of natural products as anticancer agents has a long history that began with folk medicine and has been incorporated into traditional and allopathic medicine through the years. Several drugs currently used in chemotherapy were isolated from plant species or derived from a natural prototype. According to Cragg and Newman ${ }^{1}$, over $50 \%$ of all drugs in clinical trials for anticancer activity were isolated from natural sources or are related to them.

Philadelphus coronarius L., family Hydrangeaceae, is a shrub occuring in East Asia, North America, south-east Europe and Caucasus ${ }^{2}$.

From the light petrol extract of branches and leaves taraxerol, $\beta$-amyrin, ursolic and oleanolic acid, uvaol and 3- $\beta$-28-dihydroxyoleanane-11(12),13(18)-diene were isolated, while coumarins (umbelliferone, scopolin), stigmasteryl-3- $\beta$-D-glucoside and the alkane type hydrocarbon $-\mathrm{C}_{29} \mathrm{H}_{60}$ were isolated from the chloroform branches extract ${ }^{3,4}$. Two $\gamma$-glutamylpeptides ( $\gamma$-L-glutamyl-L-2-amino-3-methylenepentanoic acid, $\gamma$-L-glutamyl-2-amino-3methylene-4-pentanoic acid) and one unsaturated amino acid (2-amino-3-methylene-4-pentenoic acid) have been formerly isolated from leaves of Philadelphus coronarius L. ${ }^{5}$. Complex 3-O-mono-, 3-O-di- and 3-O-triglycosides of flavonoids has been also detected in leaves, as well as some phenolic acids (p-hydroxybenzoic, caffeic, ferulic, protocatechuic, vanillic, chlorogenic and p-coumaric $)^{6,7}$.
An aqueous extract is used for a treatment of some gynaecological diseases in folk medicine. Literature also indicates their use in homeopathy. The ethanolic extracts of branches and leaves possess strong antibacterial activity tested on Escherichia coli, Pseudomonas aeruginosa, Staphylococcus aureus and Enterococcus faecalis. Cytotoxic activity of the same extract on HeLa cells was proved ${ }^{8,9}$. Extract from petals of Philadelphus coronarius L. showed antiradical/scavenger activity in nitroprusside and DPPH (2,2-diphenyl-1-picrylhydrazyl) assay ${ }^{10}$.

This paper describes cytotoxicity screening results of water extracts from the leaves and branches of decorative shrub Philadelphus coronarius L.

\section{MATERIAL AND METHODS}

The leaves and branches Philadelphus coronarius L. were collected in October 2003 in Arboretum, Mlyñany, Institute of Dendrobiology, Slovak Academy of Science. All samples were identified by Ing. Hotka (Arboretum Mlyňany) and voucher specimens are deposited there. Plant material was dried at room temperature at the Department of Pharmacognosy and Botany. $200 \mathrm{ml}$ water extract prepared from $20 \mathrm{~g}$ of dry leaves and branches according to the Czecho-Slovak Pharmacopoeia IV was lyophilized and stored dry at room temperature before utilization ${ }^{11}$.. Leaves yielded $15.9 \%$ and branches $11.3 \%$ of dry matter extracts. 

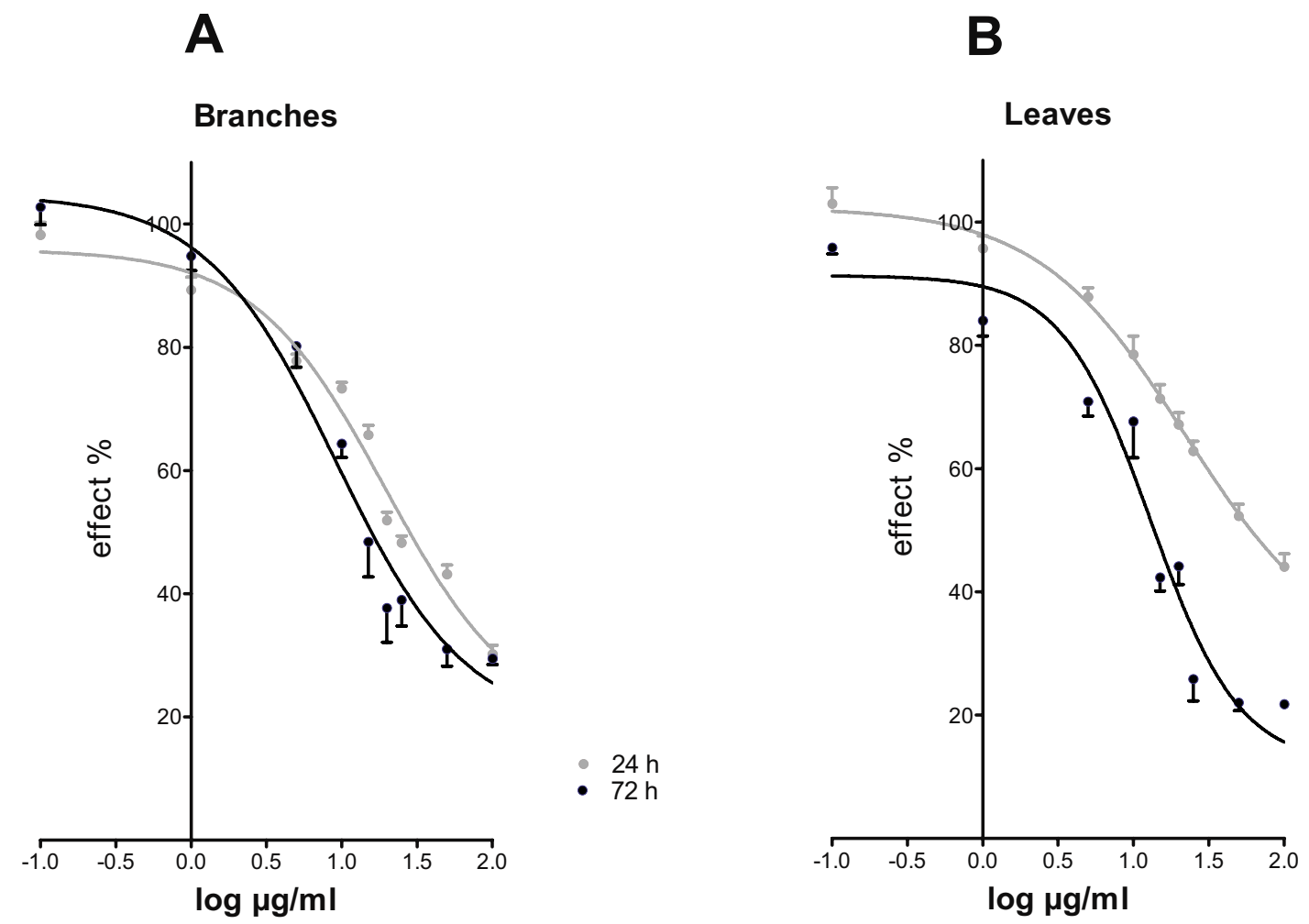

Fig. 1. MTT cytotoxicity dose response curves after $24 \mathrm{~h}$ and $72 \mathrm{~h}$ treatment of A431 cells with water extracts from branches (A) and leaves (B).

A

\section{Branches}

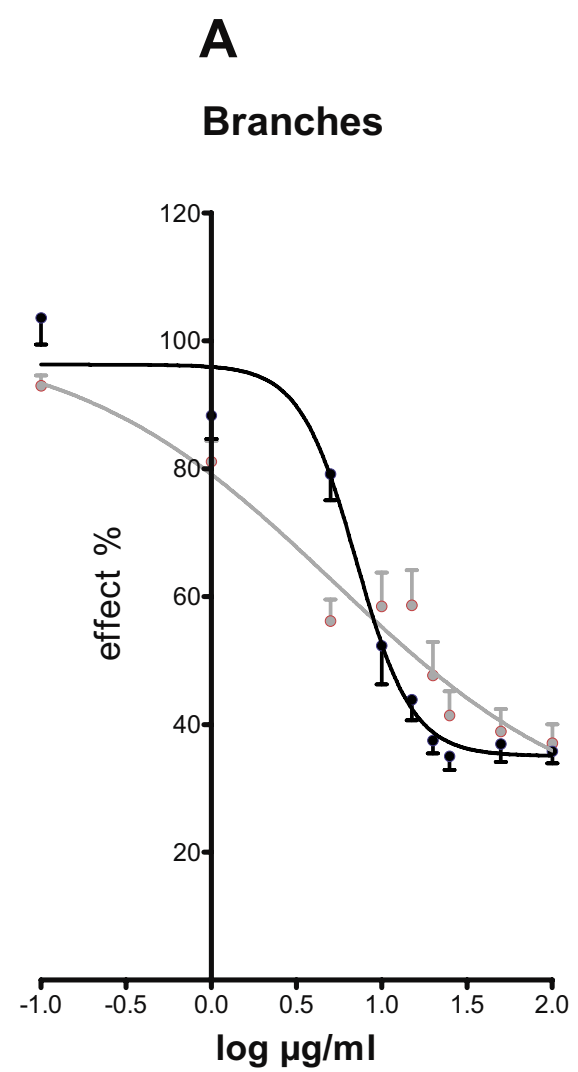

$24 \mathrm{~h}$
$-72 \mathrm{~h}$

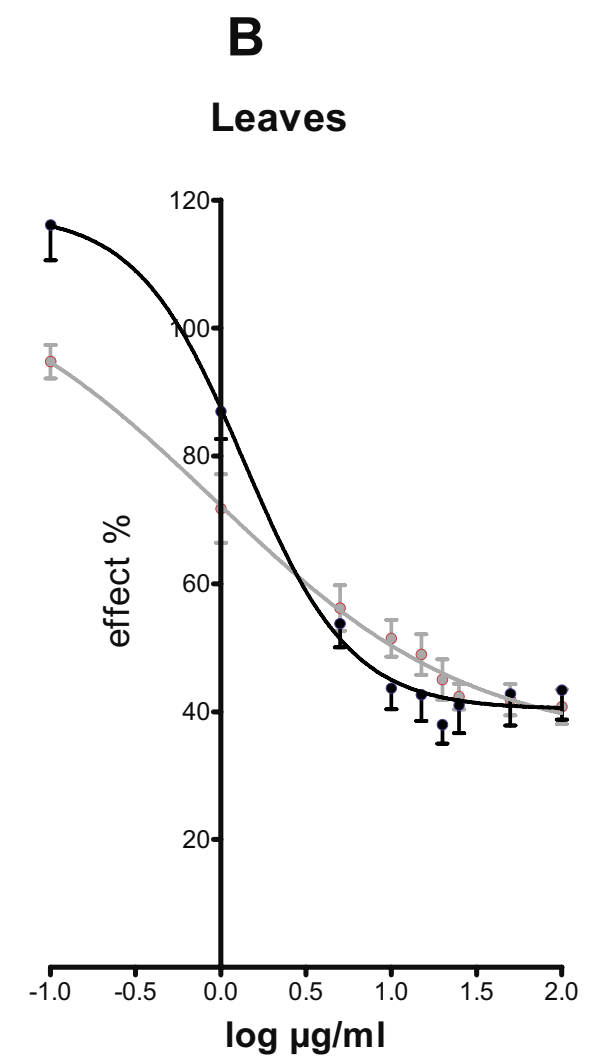

Fig. 2. MTT cytotoxicity dose response curves after $24 \mathrm{~h}$ and $72 \mathrm{~h}$ treatment of MCF-7 cells with water extracts from branches (A) and leaves (B). 
Table 1. $\mathrm{ED}_{50}$ values calculated from dose response curves on Fig. 1. and Fig. 2. The values are means $\pm \mathrm{SE}$ of three separate experiments performed in triplicates for each dose.

\begin{tabular}{|c|c|c|c|c|}
\hline \multicolumn{4}{|c|}{ ED50 Mg/ml } \\
\hline \multirow{2}{*}{} & \multicolumn{2}{|c|}{ Leaves } & \multicolumn{2}{c|}{ Branches } \\
\cline { 2 - 5 } & $24 \mathrm{~h}$ & $72 \mathrm{~h}$ & $24 \mathrm{~h}$ & $72 \mathrm{~h}$ \\
\hline A431 & $27.95 \pm 1.20$ & $15.09 \pm 4.05^{*}$ & $20.93 \pm 4.74$ & $10.03 \pm 0.36$ \\
\hline MCF7 & $2.19 \pm 0.34$ & $2.48 \pm 0.42$ & $3.81 \pm 0.76$ & $5.74 \pm 0.76^{* *}$ \\
\hline
\end{tabular}

${ }^{*} \mathrm{p}<0,05$ (24 h vs. $\left.72 \mathrm{~h}\right),{ }^{* *} \mathrm{p}<0,002(24$ h vs. $72 \mathrm{~h})$

Human skin carcinoma cell line (A431) and the human breast adenocarcinoma cell line (MCF-7) was used for toxicity study. Cells were seeded into $96-$ well plates at the density $2 \times 10^{4} /$ well in D-MEM medium supplemented with $10 \%$ FBS (Gibco BRL, Invitrogen, Paisley, Scotland) and cultured in a humidified atmosphere of $5 \% \mathrm{CO}_{2}$ and $95 \%$ air at $37^{\circ} \mathrm{C}$. The cells were cultured with individual extracts (dissolved in the same medium) in various doses for 24 and $72 \mathrm{~h}$. The culture medium and tested extracts were changed for fresh ones every $24 \mathrm{~h}$. Control cells were incubated in culture medium only.

The results are expressed as the effect of individual extracts vs control, untreated cells. MTT cytoxicity test is based on color reaction of mitochondrial dehydrogenases from living cells. The effects of extracts were expressed by $\mathrm{ED}_{50}$ values calculated from dose response curves by computer program (GraphPad Prism). The statistical significance was estimated by Student's t-test.

\section{RESULTS AND DISCUSSION}

MCF-7 cells were more susceptible to toxic effect of lower extracts doses from both, branches and leaves, as compared to A431 cells (Tab. 1). Extract from leaves were equally effective after both acute and chronic exposure on MCF-7 while $72 \mathrm{~h}$ treatment of branches extract attenuated cells response (Tab. 1). The similar extent of toxic effects due to both extracts treatment were present in A431 cells with increased sensitivity to chronic exposure of leaves extract (Tab. 1).

The results obtained demonstrate the dose and time dependent cytotoxic effects of water extracts of leaves and branches from Philadelphus coronarius L.. The character of these effects is dependent on plant parts, time of exposure and tested cells lines. According to $\mathrm{ED}_{50}$ values it is evident that MCF-7 cells are more sensitive to toxic effects measured by MTT assay as A431 cells. The chronic exposure of MCF-7 to branches extracts decreased responsivness what could indicate the presence of adaptation mechanism. On the contrary, the A431 cells become more sensitive to toxic effects of leaves and branches extracts with longer time of exposure.

We supposed that diverse magnitude of toxic effects displayed by branches and leaves extracts from
Philadelphus coronarius L. are produced by their different active substances content and relative composition. This hypothesis is supported by the previous literature data describing even different contents of various substances in different plant parts ${ }^{3,4,12}$.

This work will continue by study of the effects of individual active substances on cell proliferation and the mechanism responsible for cell growth inhibition.

\section{ACKNOWLEDGEMENTS}

This work was supported by the grant VEGA 1/1185/04 and grant UK/58/2005.

\section{REFERENCES}

1. Cragg GM, Newman DJ. (2000) Antineoplastic agents from natural sources: achievements and future directions. Expert Op Invest Drugs 9, 1-15.

2. Clapham AR, Tutin TG, Warburg EF. Flora of the British Isles, Cambrige: University Press, 1962

3. Mučaji P, Grančai D, Nagy M, Czigleová S, Budešinský M, Ubik K. (2001) Nonpolar components of the leaves of Philadelphus coronarius L. Čes Slov Farm 50, 274-6.

4. Mučaji P, Grančai D, Nagy M, Czigleová S, Ubik K. (2001) Obsahové látky konárov Philadelphus coronarius L. Farm obzor 70, 311-4. (In Slovak)

5. Campos L, Marlier M, Dardenne G, Casimir J. (1983) ХGlutamylpeptides Philadelphus coronarius. Phytochemistry 22, 2507-8.

6. Bohm BA, Nicholls KW, Bhat UG. (1985) Flavonoids of the Hydrangeaceae Dumortier. Biochem Syst Ecol 13, 441-5.

7. Hegnauer R. Chemotaxonomie der Pflanzen. Band IV. Stuttgart: Birkhauser Verlag, 1973.

8. Jantová S, Nagy M, Ružeková L, Grančai D. (2000) Antibacterial activity of plant extracts from the families Fabaceae, Oleaceae, Philadelphaceae, Rosaceae and Staphyleaceae. Phytother Res 14, 601-4.

9. Jantová S, Nagy M, Ružeková L, Grančai D. (2001) Cytotoxic effects of plant extracts from the families Fabaceae, Oleaceae, Philadelphaceae, Rosaceae and Staphyleaceae. Phytother Res 15, 22-5.

10. Klečáková J, Chobot V, Jahodář L, Laakso I, Vrchová P. (2004) Antiradical activity of petals of Philadelphus coronarius. Cent Eur J Public Health. 12, Suppl: S39-40.

11. PhBs IV. Pharmacopoeia Bohemoslovaca $4^{\text {th }}$ Edn., vol.III. Avicenum, Praha. 1987. p. 43-45

12. Grančai D, Mučaji P, Nagy M. (1999) Stanovenie vybraných sekundárnych metabolitov a extraktívnych látok vo Philadelphus coronarius L. Čes Slov Farm 48, 265-7. 